\title{
IDENTIFIKASI KETERHUBUNGAN RUMAH SUSUN DAN TRANSPORTASI PUBLIK UNTUK MENUNJANG PENGEMBANGAN KAWASAN PRIORITAS DI BATAM
}

\author{
(The Identification of Vertical Housing and Public Transportation Connectivity \\ to Support Batam High Priority Areas Development)
}

\author{
Firmansyah Bachtiar ${ }^{1}$ \\ ${ }^{1}$ Program Studi Arsitektur, Universitas Tanri Abeng \\ Email: firmansyah.bachtiar@tau.ac.id
}

\begin{abstract}
Abstrak
Peran Batam sebagai kawasan pelabuhan dan perdagangan bebas berimbas pada peningkatan kegiatan di sektor industri, kepelabuhanan dan perdagangan jasa. Hal ini terlihat dari meningkatnya jumlah populasi Batam dari sekitar 6.000 jiwa di tahun 1970 menjadi lebih dari 1 juta jiwa di tahun 2020. Untuk menggenjot investasi agar dapat bersaing dengan Singapura dan Johor, telah disusun Rencana Induk Pengembangan KPBPB Batam, Bintan, Karimun yang menetapkan beberapa proyek infrastruktur dan kawasan yang diharapkan dapat memperluas peluang masuknya investor ke Batam. Pengembangan kawasan prioritas tersebut dapat menjadi pemicu penambahan jumlah penduduk yang berimbas pada peningkatan kebutuhan hunian khususnya untuk pekerja dan MBR. Dalam kondisi saat ini, sudah terdapat beberapa Rumah Susun di Batam untuk menunjang kebutuhan hunian pekerja industri, dimana pada komplek Rumah Susun tersebut masih diimungkinkannya ada pengembangan kapasitas untuk mengantisipasi kebutuhan hunian karena munculnya kawasan strategis baru. Kajian ini berusaha melihat posisi dan peran Rumah Susun yang ada saat ini dan potensinya dari segi jarak untuk mendukung proyek kawasan prioritas yang ada, serta potensi keterhubungan Rumah Susun tersebut dengan transportasi massal yang dapat menunjang kebutuhan mobilitas penghuni ke tempat kerja nantinya.
\end{abstract}

Kata kunci: Rumah Susun, transportasi, perumahan, prioritas, batam

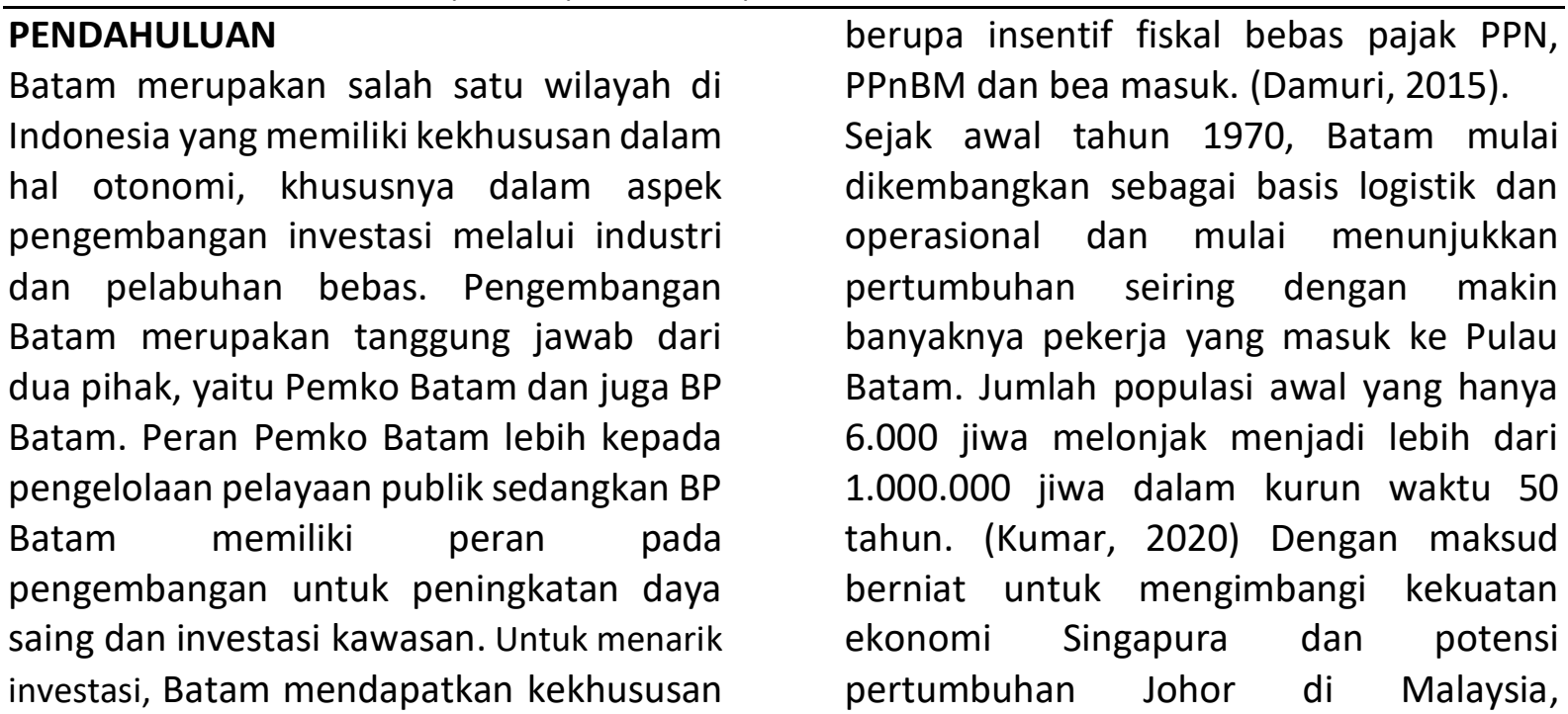


Pemerintah Indonesia menempatkan Batam sebagai kawasan khusus yang berperan untuk menarik investasi pada jalur ekonomi strategis di sekitar Selat Malaka dengan pengembangan industri manufaktur, logistik, pariwisata dan industri penerbangan. (Kemenko Bidang Perekonomian Republik Indonesia, 2020). Seiring dengan fokus pengembangannya pada kawasan industri, Batam kemudian menjadi salah satu tujuan para pencari kerja dari berbagai wilayah di sekitar Kepulauan Riau, pulau Sumatera bahkan dari berbagai wilayah Indonesia. Peningkatan migran tersebut berbanding lurus dengan kebutuhan akan tempat tinggal bagi pendatang. Banyaknya migran yang datang tidak sebanding dengan ketersediaan fasilitas perumahan (khususnya untuk Masyarakat Berpenghasilan Rendah/MBR), menyebabkan lambat laun munculnya rumah liar (squatters) yang berada di sekitar kawasan industri dan pelabuhan. Kemunculan rumah liar semakin bertambah di Batam, dimana hingga tahun 2021 menurut data Dinas Perumahan, Permukiman dan Taman Kota Batam, terdapat lebih dari 33.000 rumah liar yang masih tersebar di beberapa pelosok kota Batam.

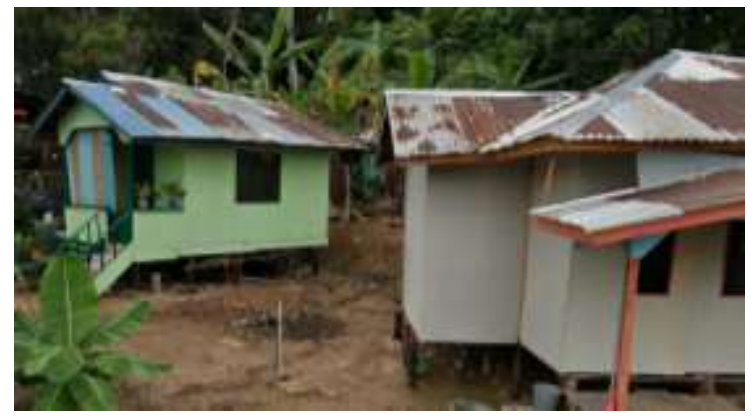

Gambar 1. Kondisi Rumah Liar di Sekupang (Sumber: Hasil Observasi)

Kawasan Batam sejak tahun 2017 secara resmi ditetapkan sebagai Kawasan Perdagangan Bebas dan Pelabuhan Bebas (KPBPB) (Pemerintah Republik Indonesia, 2017) dan saat ini Rencana Induk
Pengembangan KPBPB Batam, Bintan, Karimun sedang diproses untuk diterbitkan Pepres yang akan mengarahkan pengembangan kawasan dan infrastruktur prioritas yang ada di Batam. Terdapat sekitar 57 kawasan dan infrastruktur prioritas yang akan dikembangkan di wilayah Batam, baik di pulau-pulau besar maupun kecil untuk mendukung peningkatan masuknya investasi ke Batam. (Kemenko Bidang Perekonomian, 2020).

Adanya arahan pengembangan kawasan dan infrastruktur prioritas ini memunculkan potensi terjadinya peningkatan jumlah penduduk yang akan berimbas pada peningkatan kebutuhan akan hunian. Untuk mengatasi permasalahan kebutuhan rumah, Pemkot Batam dan BP Batam sudah melakukan beberapa upaya penyediaan perumahan antara lain pembangunan Rumah Susun untuk pekerja maupun penyediaan Kavling Siap Bangun (KSB) bagi masyarakat terdampak relokasi. Lokasi pembangunan Rumah Susun dan KSB tersebut tersebar di beberapa lokasi yang merupakan tanah pengelolaan BP Batam, dan saat ini sebagian besar dalam kondisi yang sudah relatif penuh.

Rumah Susun yang ada saat ini antara lain berfungsi untuk memenuhi kebutuhan pekerja industri dan juga perdagangan jasa, namun seringkali juga sering ditemukan bahwa penghuni Rumah Susun adalah bukan segmen yang sesuai sasaran (Martiono, 2020). Adanya ketidaksesuaian segmen penghuni selain karena belum siapnya masyarakat tinggal dalam bentuk hunian vertikal, selain juga karena Rumah Susun yang ada relatif jauh dari tempat mencari nafkah.

Transportasi publik di Batam belum terlalu populer dikarenakan pengembangan Batam saat ini lebih diorientasikan untuk 
kendaraan pribadi, hal ini dapat terlihat dari dimensi jalan raya yang lebar dan minimnya armada transportasi umum dan jalur pejalan kaki. Konsep kota yang berorientasikan pada kendaraan ini dikhawatirkan akan memunculkan kawasan perkotaan dengan masalah baru, yaitu kepadatan dan kemacetan lalu lintas khususnya saat kawasan prioritas yang baru makin berkembang.

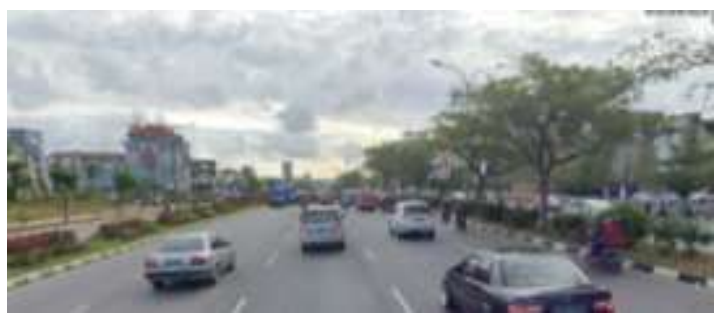

Gambar 2. Kondisi Jalan dengan ROW lebar di Batam

(Sumber: Hasil Observasi)

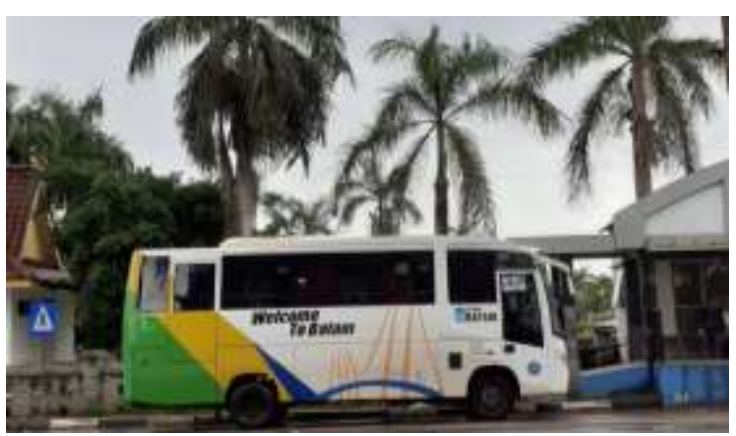

Gambar 3. Trans Batam yang Sudah Beroperasi di Beberapa Trayek

(Sumber: Antara News)

Keberadaan Rumah Susun sangat penting sebagai opsi hunian bagi pekerja, karena keterbatasan lahan di Batam saat ini. Namun perlu diperhatikan bahwa suatu Rumah Susun yang tidak terhubung dengan jalur transportasi umum yang memadai akan cenderung menjadi kontraproduktif karena akan memberikan beban biaya tambahan kepada penghuni. Oleh karena itu perlu dikaji, apakah Rumah Susun yang ada saat ini dari segi lokasi dapat berpotensi sebagai pendukung dari pengembangan kawasan-kawasan prioritas yang baru, sehingga dapat menjadi rekomendasi bagi pihak terkait untuk mengintegrasikan pengembangan kawasan prioritas dengan kawasan Rumah Susun sebagai pendukungnya, dengan lokasi yang tidak jauh dari lokasi tempat kerja atau minimal terhubung oleh transportasi publik.

\section{PERTANYAAN PENELITIAN}

Penelitian ini dilakukan untuk secara lebih mendalam melihat potensi lokasi Rumah Susun eksisting da di Kota Batam dan perannya untuk mendukung pengembangan kawasan prioritas Batam ke arah yang berkelanjutan. Penelitian dari Martiono (2020) sebelumnya sudah melakukan kajian terhadap peran rumah susun dalam mengatasi isu Ruli dan kumuh di Batam dengan data di tahun 2018. Kajian kali ini mencoba melihat gambaran kondisi lokasi Rumah Susun yang ada terhadap rencana pengembangan kawasan prioritas di wilayah Batam yang sudah ditetapkan oleh Rencana Induk KPBPB Batam, Bintan, Karimun. Beberapa hal yang menjadi pertanyaan peneilitian adalah:

- Apakah sebaran lokasi Rumah Susun yang ada sudah menunjang potensi pemenuhan kebutuhan hunian untuk rencana pengembangan kawasan prioritas?

- Apakah lokasi Rumah Susun yang ada sudah terlayani dengan rencana transportasi publik yang akan mendukung mobilitas penghuni untuk bekerja di kawasan-kawasan prioritas yang berkembang di masa depan?

\section{TINJAUAN PUSTAKA}

Perumahan dan kawasan permukiman adalah satu kesatuan sistem yang terdiri atas pembinaan, penyelenggaraan perumahan, penyelenggaraan kawasan permukiman, pemeliharaan dan perbaikan, pencegahan dan peningkatan kualitas terhadap perumahan kumuh dan permukiman kumuh, penyediaan tanah, pendanaan dan sistem pembiayaan, serta 
peran masyarakat (Republik Indonesia, 2011). Tiga aspek utama dalam penyediaan perumahan, meliputi aspek supply, aspek demand dan aspek need. Kebutuhan rumah tidak hanya dibaca pada sisi kuantitas, akan tetapi dari sisi kualitas yang dikenali sebagai bentuk kesadaran akan keberadaan rumah atau ruang (existence space) hunian oleh penghuni (Sabarudin, 2018).

Permasalahan yang terjadi seiring dengan meningkatnya populasi penduduk di Kota Batam adalah masih maraknya rumah liar/rumah bermasalah terkonsentrasi di daerah sekitar kawasan industri dan kekurangsiapan dalam mengantisipasi kecepatan dan pertumbuhan fisik dan dan fungsional kawasan (Dinas Tata Kota, Kota Batam, 2009). Para urbanis yang datang ke kota secara naluriah membangun shelter sesuai dengan kemampuan dengan bahan seadanya. (Sabarudin, 2018). Hal tersebut membuat kawasan permukiman Ruli berkembang menjadi kawasan padat dan kumuh. Maraknnya Ruli juga membuat beberapa rencana pengembangan menjadi terhambat karena kemelut maslaah relokasi lahan dan juga serapan anggaran untuk relokasi pemukim liar.

Upaya yang dilakukan oleh Pemko Batam dan BP Batam antara lain berupa penyediaan Rumah Susun yang dikembangkan terutama pada beberapa lokasi di sekitar fungsi industri. Pengembangan hunian vertikal saat ini masih cenderung bersifat parsial dan eksklusif, belum direncanakan dalam suatu kawasan pengembangan hunian vertikal yang ditunjang oleh prasarana dan sarana yang kompak dan terintegrasi.

Dilihat dari jumlah unit rusunawa yang telah berhasil dibangun oleh Pemerintah Kota Batam dibandingkan dengan jumlah total hunian liar yang ada, masih terlihat ketimpangan yang sangat jauh.
Pemerintah Kota Batam hanya sanggup menyediakan kurang dari $2 \%$ kebutuhan perumahan untuk masyarakat dengan tingkat ekonomi menengah kebawah (Murtiono, 2020).

Selain keterbatasan kemampuan untuk pembangunan Rumah Susun, minat menghuni Rumah Susun dalam konteks pembentukan ruang sangat tergantung dari persepsi dan motivasi masyarakat serta lokasi hunian. Masih ada peluang cukup tinggi minat masyarakat untuk tinggal di hunian vertikal, tetapi dibutuhkan perencanaan yang matang dan terpadu agar masyarakat bisa tertarik. (Murbaintoro, 2009). Salah satu upaya yang dapat membantu minat bagi masyarakat tinggal di Rumah Susun adalah keterjangkauan terhadap transportasi publik. Batam sudah memiliki rencana pengembangan transportasi massal dalam bentuk LRT dan pengembangan BRT di masa datang (Kemenko Bidang Perekonomian, 2020). Konsep integrasi Rumah Susun dan transportasi publik ini antara lain dapat mengambil prinsip dan esensi dalam pengembangan suatu Kawasan Transit Oriented Development yaitu jangkauan 10 menit berjalan kaki (radius $400 \mathrm{~m} \mathrm{~s} / \mathrm{d} 800 \mathrm{~m}$ ) menuju transportasi umum (Kementerian Pekerjaan Umum dan Perumahan Rakyat, 2020). Dengan dekatnya jarak antara Rumah Susun dengan akses transportasi publik, maka potensi Rumah Susun akan menarik minat masyarakat menjadi semakin besar.

\section{METODE}

Metode riset dilakukan secara deskriptif, melaui hasil observasi dan studi data yang dilakukan melalui mapping dan overlay terhadap aspek sebaran Rumah Susun, sebaran kawasan prioritas, dan rute/jalur pengembangan transportasi publik.

Pemetaan dilakukan terhadap lokasi Rumah Susun eksisting, baik yang dikelola 
oleh Pemko Batam, BP Batam maupun kementerian/lembaga lain. Hasil pemetaan lokasi Rumah Susun eksisting lalu dilakukan overlay terhadap pemetaan posisi program/proyek prioritas pada Rencana Induk KPBPB BBK yang berpotensi menghasilkan peningkatan populasi penduduk.

Identifikasi rencana pengembangan transportasi publik dilakukan dengan pemetaan terhadap moda transportasi BRT dan LRT yang direncanakan akan dioperasionalkan di Batam. Hasil dari analisa kebutuhan hunian dan pemetaan lokasi dilakukan untuk melihat peran lokasi Rumah Susun yang ada untuk mendukung kebutuhan akan hunian pekerja dan MBR, dilihat dari kedekatan antara Rumah Susun dan kawasan prioritas serta keterhubungan transportasi publik yang ada.

\section{ANALISA DAN HASIL}

\section{Identifikasi Lokasi Rumah Susun}

Berdasarkan data dari Dinas Perumahan, Permukiman dan Pertamanan Kota Batam, terdapat total 80 twin blok dan sekitar 7.361 unit Rumah Susun yang tersebar di 17 lokasi Rumah Susun di pelosok Pulau Batam. Sehubungan dengan pertumbuhan kawasan strategis ekonomi yang terpusat di Pulau Batam, sebaran Rumah Susun belum ditemui di Pulau Rempang, Galang, dan Galang Baru karena lokasinya belum berkembang. Pada pulau-pulau tersebut, perumahan yang ada masih berupa kelompok permukiman yang tumbuh sporadis di sekitar pantai atau jalan Trans Barelang.

Rumah Susun yang ada saat ini sebagian besar diperuntukkan untuk segmen pekerja MBR yang banyak bekerja di sektor industri, pelabuhan dan perdagangan jasa. Rumah Susun yang dikelola BP Batam yang ada di Batam umumnya saat ini dalam kondisi yang memiliki okupansi $70-85 \%$ sesuai data dari Ameniti BP Batam tahun 2020. Rumah Susun yang dikelola oleh pihak lain (Pemko, Jamsostek, Perumnas) juga memiliki tingkat okupansi yang relatif serupa. Rumah Susun yang berkembang di Batam saat ini lebih dalam bentuk Rumah Susun Sewa (Rusunawa), dimana Rumah Susun Milik (Rusunami) masih belum diminati karena opsi kepemilikian rumah tapak bagi segmen masyarakat non subsidi yang masih cukup tersedia di Batam. Rumha Susun Sewa yang ada saat ini lebih diperuntukkan untuk segmen MBR dan pekerja.
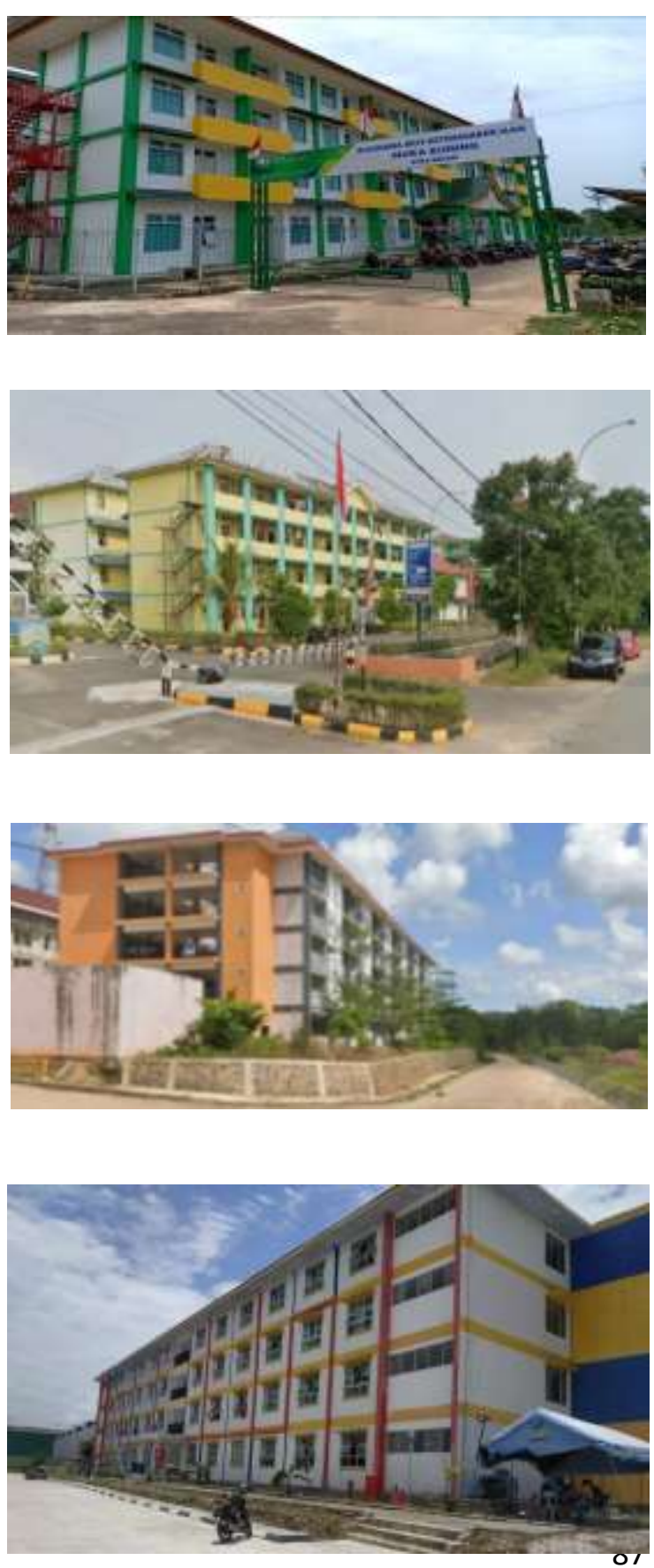


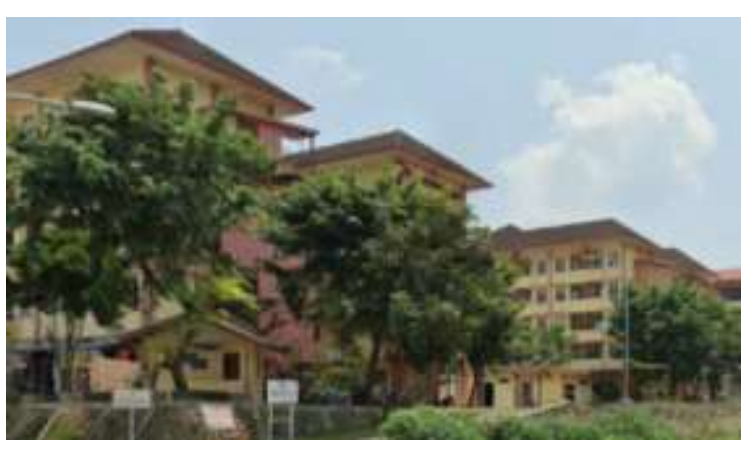

Gambar 4. Kondisi Rumah Susun di Batam (Sumber: Hasil Observasi)

Tabel 1. Sebaran Rumah Susun di Batam

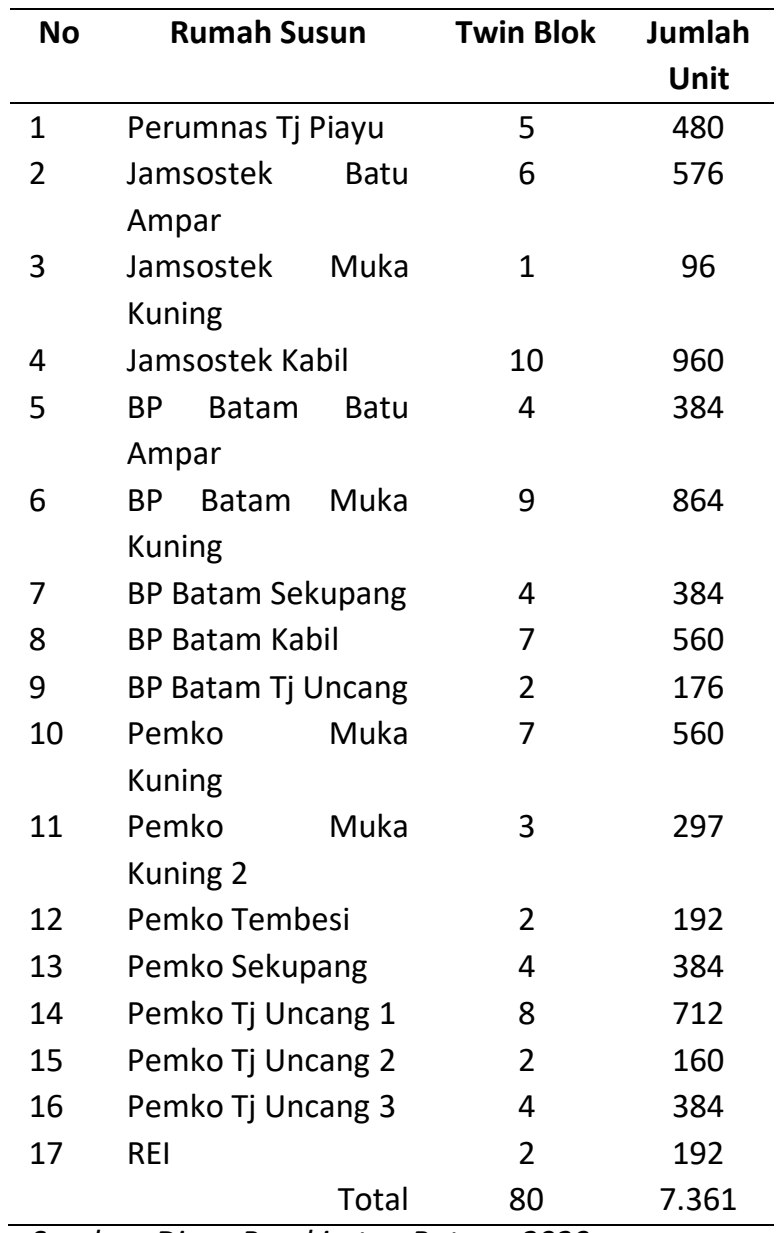

Sumber: Dinas Perakimtan Batam, 2020

\section{Identifikasi Pengembangan Kawasan Prioritas}

Pengembangan kawasan prioritas dalam Rencana Induk KPBPB BBK diarahkan berdasarkan berbagai petimbangan antara lain:
1. Keterkaitan antara core bisnis dan visi pengembangan Kawasan BBKT.

2. Besaran nilai investasi.

3. Besaran daya ungkit / coverage.

4. Kewenangan pelaksanaan.

5. Kesesuaian terhadap Rencana Tata Ruang.

Pengembangan kawasan prioritas mencakup pengembangan berbasis industri, perdagangan jasa dan pariwisata. Proyek yang berpotensi memunculkan Ionjakan populasi dan kebutuhan hunian yang besar adalah CBD Teluk Tering Batam Center, CBD Pantai Barat, KEK Nongsa, KEK BAT, dan KEK Aerocity. Pengembangan secara intensitas tinggi terutama berada di proyek CBD Batam Center dan CBD Pantai Barat yang diproyeksikan akan memunculkan populasi tambahan hingga ratusan ribu orang pada saat seluruh kawasan terbangun. Kawasan prioritas lain yang juga akan memunculkan populasi pekerja yang cukup besar adalah pada kawasan terkait industri, seperti Tanjung Piayu dan juga daerah di sekitar Hub Logistic Bandara Hang Nadim, Pelabuhan Batu Ampar dan Kabil yang banyak menyerap tenaga kerja.

Tabel 2. Proyek Kawasan Prioritas di Pulau Batam

\begin{tabular}{|c|c|c|}
\hline $\begin{array}{c}\text { Proyek Kawasan } \\
\text { Prioritas }\end{array}$ & Sektor & Lokasi \\
\hline $\begin{array}{l}\text { Kawasan Industri } \\
\text { Tanjung Piayu }\end{array}$ & Industri & Sei Beduk \\
\hline KEK Nongsa & $\begin{array}{l}\text { Ekonomi } \\
\text { Digital }\end{array}$ & Nongsa \\
\hline $\begin{array}{l}\text { KEK Batam Aero } \\
\text { Technic }\end{array}$ & Penerbangan & Nongsa \\
\hline KEK Aerocity & Penerbangan & Nongsa \\
\hline $\begin{array}{l}\text { KEK Kesehatan } \\
\text { Sekupang }\end{array}$ & Kesehatan & Sekupang \\
\hline $\begin{array}{l}\text { CBD Teluk Tering } \\
\text { Batam Center }\end{array}$ & $\begin{array}{c}\text { Perdagangan } \\
\text { Jasa }\end{array}$ & $\begin{array}{l}\text { Batam } \\
\text { Kota }\end{array}$ \\
\hline CBD Pantai Barat & $\begin{array}{c}\text { Perdagangan } \\
\text { Jasa }\end{array}$ & Sekupang \\
\hline $\begin{array}{l}\text { Wisata Tanjung } \\
\text { Pinggir }\end{array}$ & Wisata & Sekupang \\
\hline
\end{tabular}




\begin{tabular}{ccc}
\hline $\begin{array}{c}\text { Proyek Kawasan } \\
\text { Prioritas }\end{array}$ & Sektor & Lokasi \\
\hline Pasar Induk Jodoh & $\begin{array}{c}\text { Perdagangan } \\
\text { Jasa }\end{array}$ & Lubuk Baja \\
& &
\end{tabular}

Sumber: Rencana Induk BBKT, 2020

Terdapat 9 kawasan yang masuk dalam prioritas pengembangan KPBPB Batam yang berpotensi memunculkan kebutuhan hunian dalam jumlah besar karena peningkatan jumlah pekerja di kawasankawasan tersebut. Untuk dapat melihat posisi Rumah Susun yang ada sekarang terhadap rencana pengembangan kawasan tersebut, maka dilakukan pemetaan lokasi Rumah Susunawa dan proyek prioritas di wilayah KPBPB Batam.

Tabel 3. Proyek Kawasan Prioritas di Pulau Batam

\begin{tabular}{|c|c|c|}
\hline No & $\begin{array}{c}\text { Proyek Kawasan } \\
\text { Prioritas }\end{array}$ & $\begin{array}{c}\text { Potensi Kebutuhan } \\
\text { Hunian }\end{array}$ \\
\hline 1 & $\begin{array}{l}\text { Kawasan Industri } \\
\text { Tanjung Piayu }\end{array}$ & $\begin{array}{l}\text { Hunian untuk pekerja } \\
\text { industri, dan akan } \\
\text { secara signifikan } \\
\text { menambah jumlah } \\
\text { penduduk di kawasan } \\
\text { tersebut karena saat ini } \\
\text { relatif belum } \\
\text { berkembang. }\end{array}$ \\
\hline 2 & KEK Nongsa & $\begin{array}{l}\text { Hunian untuk pekerja } \\
\text { industri digital, industri } \\
\text { kreatif dan pekerja di } \\
\text { bidang hospitality dari } \\
\text { resort-resort yang ada } \\
\text { di Nongsa. }\end{array}$ \\
\hline 3 & $\begin{array}{l}\text { KEK Batam Aero } \\
\text { Technic }\end{array}$ & $\begin{array}{l}\text { Hunian untuk pekerja } \\
\text { industri MRO dan juga } \\
\text { pekerja di Bandara } \\
\text { Hang Nadim }\end{array}$ \\
\hline 4 & KEK Aerocity & $\begin{array}{l}\text { Hunian untuk pekerja } \\
\text { terkait kebandaraan } \\
\text { maupun pekerja yang } \\
\text { muncul karena } \\
\text { pengembangan fungsi } \\
\text { baru pada kawasan. }\end{array}$ \\
\hline 5 & $\begin{array}{l}\text { KEK Kesehatan } \\
\text { Sekupang }\end{array}$ & $\begin{array}{l}\text { Hunian untuk pekerja } \\
\text { di beberapa fasilitas } \\
\text { kesehatan yang } \\
\text { dikembangkan di } \\
\text { Sekupang, termasuk }\end{array}$ \\
\hline
\end{tabular}

\begin{tabular}{|c|c|c|}
\hline No & $\begin{array}{c}\text { Proyek Kawasan } \\
\text { Prioritas }\end{array}$ & $\begin{array}{c}\text { Potensi Kebutuhan } \\
\text { Hunian }\end{array}$ \\
\hline & & $\begin{array}{l}\text { pekerja untuk fungsi } \\
\text { pendukung seperti } \\
\text { sektor komersial dan } \\
\text { hospitality. }\end{array}$ \\
\hline 6 & $\begin{array}{l}\text { CBD Teluk Tering } \\
\text { Batam Center }\end{array}$ & $\begin{array}{l}\text { Hunian untuk pekerja } \\
\text { di perkantoran bisnis, } \\
\text { fasilitas perdangan jasa }\end{array}$ \\
\hline & & $\begin{array}{ll}\text { maupu sektor } \\
\text { pendukungnya. }\end{array}$ \\
\hline 7 & CBD Pantai Barat & $\begin{array}{l}\text { Hunian untuk pekerja } \\
\text { di perkantoran bisnis, } \\
\text { fasilitas perdagangan }\end{array}$ \\
\hline & & $\begin{array}{l}\text { jasa maupu sektor } \\
\text { pariwisatanya. }\end{array}$ \\
\hline 8 & $\begin{array}{l}\text { Wisata Tanjung } \\
\text { Pinggir }\end{array}$ & $\begin{array}{l}\text { Hunian untuk pekerja } \\
\text { di sektor pariwisata } \\
\text { dan penunjangnya. }\end{array}$ \\
\hline 9 & Pasar Induk Jodoh & $\begin{array}{l}\text { Hunian untuk pekerja } \\
\text { di sektor pariwisata } \\
\text { dan penunjangnya. }\end{array}$ \\
\hline
\end{tabular}

Sumber: Hasil Analisis

\section{Pemetaan Rumah Susun terhadap Rencana Kawasan Prioritas}

Pemetaan dilakukan dengan mengidentifikasi posisi Rumah Susun dan kedekatannya dengan rencana pengembangan Kawasan Prioritas. Jarak ideal lokasi Rumah Susun adalah apabila dapat ditempuh dalam 10 menit berjalan kaki (400-800 meter) dengan kawasan pengembangan prioritas. Pertimbangan ini disesuaikan dengan kemudahan mobilitas penghuni untuk bekerja yang dapat mengutamakan berjalan kaki tanpa harus menggunakan kendaraan. Lingkaran merah pada Gambar 5 menunjukkan radius ideal aksebilitas kawasan prioritas terhadap lokasi hunian, sedangkan lingkaran kuning pada Gambar 5 menunjukkan lokasi Rumah Susun eksisting. 


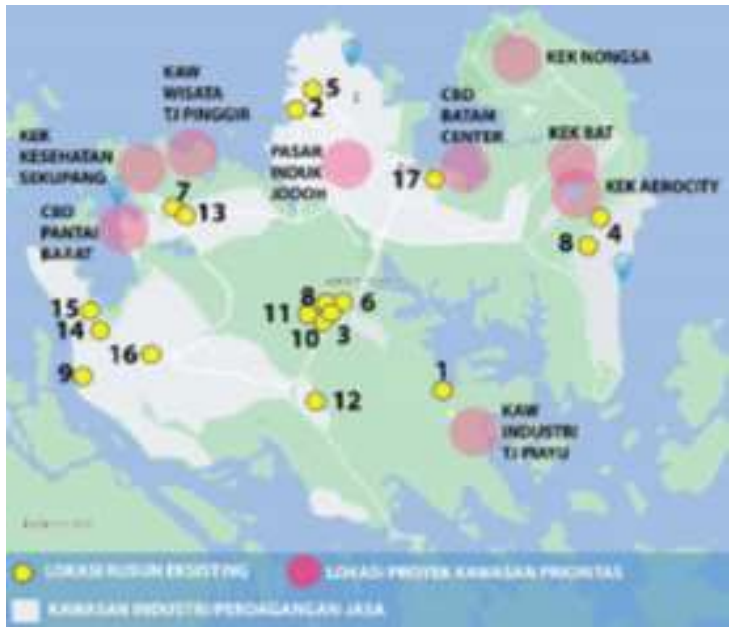

Gambar 5. Lokasi Rumah Susun terhadap Rencana Kawasan Prioritas

(Sumber: Hasil Analisis)

Berdasarkan hasil pemetaan, dapat dilihat beberapa temuan sebagai berikut:

- Rumah Susun eksisting sebagian besar berada di sekitar kawasan perindustrian, perdagangan jasa dan pelabuhan, di sekitar Batu Ampar, Tanjung Uncang, Muka Kuning dan Sekupang.

- Sebagian besar lokasi Rumah Susun berada di sisi utara dan barat Pulau Batam, dimana pada lokasi tersebut merupakan area yang telah berkembang lama sebagai kawasan industri dan perdagangan-jasa.

- Pada rencana pengembangan kawasan prioritas, hanya ada beberapa lokasi Rumah Susun yang relatif dekat (Rumah Susun Kabil, Rumah Susun REI). Walaupun termasuk dekat, namun keseluruhan lokasi Rumah Susun yang ada umumnya diluar jangkauan jarak nyaman berjalan kaki, sehingga mobilitas antara tempat tinggal dan kawasan prioritas tetap memerlukan kendaraan.

- Jika melihat dari potensi layanan Rumah Susun terdekat dari kawasan prioritas pengembangan yang ada, maka dapat dilihat rata-rata Rumah Susun yang ada saat ini berjarak 2-6 $\mathrm{km}$ dengan kawasan pengembangan prioritas. Jarak tersebut relatif jauh sehingga perlu didukung oleh sarana transportasi massal untuk memudahkan mobilitas penghuni menuju rencana kawasan pengembangan prioritas.

Tabel 4. Potensi Dukungan Rumah Susun Terdekat terhadap Kawasan Pengembangan Prioritas

\begin{tabular}{|c|c|c|}
\hline No & $\begin{array}{c}\text { Proyek Kawasan } \\
\text { Prioritas }\end{array}$ & $\begin{array}{c}\text { Potensi Dukungan } \\
\text { Rumah Susun } \\
\text { Terdekat }\end{array}$ \\
\hline 1 & $\begin{array}{l}\text { Kawasan Industri } \\
\text { Tanjung Piayu }\end{array}$ & $\begin{array}{l}\text { Rusun Perumnas } \\
\text { Tanjung Piayu, berjarak } \\
\text { sekitar } 3 \mathrm{~km}\end{array}$ \\
\hline 2 & KEK Nongsa & $\begin{array}{l}\text { Rusun Jamsostek dan } \\
\text { BP di Kabil, berjarak } \\
\text { sekitar } 6 \mathrm{~km}\end{array}$ \\
\hline 3 & $\begin{array}{l}\text { KEK Batam Aero } \\
\text { Technic }\end{array}$ & $\begin{array}{l}\text { Rusun Jamsostek dan } \\
\text { BP di Kabil, berjarak } \\
\text { sekitar } 4 \mathrm{~km}\end{array}$ \\
\hline 4 & KEK Aerocity & $\begin{array}{l}\text { Rusun Jamsostek dan } \\
\text { BP di Kabil, berjarak } \\
\text { sekitar } 2 \mathrm{~km}\end{array}$ \\
\hline 5 & KEK Kesehatan & Rusun Pemko dan BP di \\
\hline & Sekupang & $\begin{array}{l}\text { Sekupang, berjarak } \\
\text { sekitar } 3 \mathrm{~km}\end{array}$ \\
\hline 6 & $\begin{array}{l}\text { CBD Teluk Tering } \\
\text { Batam Center }\end{array}$ & $\begin{array}{l}\text { Rusun REI di Kabil, } \\
\text { berjarak sekitar } 3 \mathrm{~km}\end{array}$ \\
\hline 7 & CBD Pantai Barat & $\begin{array}{l}\text { Rusun Pemko dan BP di } \\
\text { Sekupang, berjarak } \\
\text { sekitar } 4 \mathrm{~km}\end{array}$ \\
\hline 8 & $\begin{array}{l}\text { Wisata Tanjung } \\
\text { Pinggir }\end{array}$ & $\begin{array}{l}\text { Rusun Pemko dan BP di } \\
\text { Sekupang, berjarak } \\
\text { sekitar } 3 \mathrm{~km}\end{array}$ \\
\hline 9 & Pasar Induk Jodoh & $\begin{array}{l}\text { Rusun Jamsostek dan } \\
\text { BP di Batu Ampar, } \\
\text { berjarak sekitar } 3 \mathrm{~km}\end{array}$ \\
\hline
\end{tabular}

Sumber: Hasil Analisis

\section{Identifikasi Rencana Pengembangan Transportasi}

Pengembangan transportasi massal di Batam akan dikembangkan dalam bentuk Light Rapid Transit (LRT) dengan rute Batam Center-Tanjung Uncang $(28,4 \mathrm{~km})$, Hang Nadim-Sei Jodoh $(16,6 \mathrm{~km})$, Hang Nadim-Telaga Punggur $(17,5 \mathrm{~km})$ dan Sei 
Jodoh-Sekupang (13,8 km). Direncanakan juga pengembangan TOD di beberapa lokasi stasiun LRT seperti di Bandara Hang Nadim, Hang Tuah, Sembakau Forest, Belian Waterfront, Batam Center, pasir Putih, Bengkong Laut, Yos Sudarso, Batu Ampar, Sei Jodoh dan Dipo. (BP Batam, 2017).

Selain pengembangan LRT, direncanakan pula adanya pengembangan Bus Rapid Transit/BRT yang terdiri dari 2 fase, yaitu fase 1 terdiri dari 38 stasiun dan 25,83 km membentang dari Panbil hingga ke Dotamana dan Harbour Bay. Fase 2 pengembangan 29 stasiun BRT sepanjang 25,33 km menghubungkan hingga ke Bukit Tempayan, Sungai Harapan dan Hang Nadim.

Potensi peningkatan konektivitas kawasan melalui pengembangan transportasi massal ini akan membantu pengembangan kota yang lebih berkelanjutan. Pengembangan Rumah Susun yang terintegrasi transportasi publik juga akan meningkatkan nilai ekonomi bagi kegiatan di sekitar Rumah Susun.

\section{Keterhubungan Lokasi Rumah Susun dengan Akses Transportasi Publik Menuju Kawasan Strategis}

Pemetaan dilakukan dengan mengidentifikasi posisi Rumah Susun dan jalur transportasi umum (LRT/BRT) yang melintas di sekitarnya. Konektivitas yang muncul pada suatu Rumah Susun dapat memberikan dukungan positif terhadap Rumah Susun tersebut, khususnya terkait potensi ketertarikan penghuni untuk tinggal di Rumah Susun karena kemudahan transportasi ke tempat kerja.

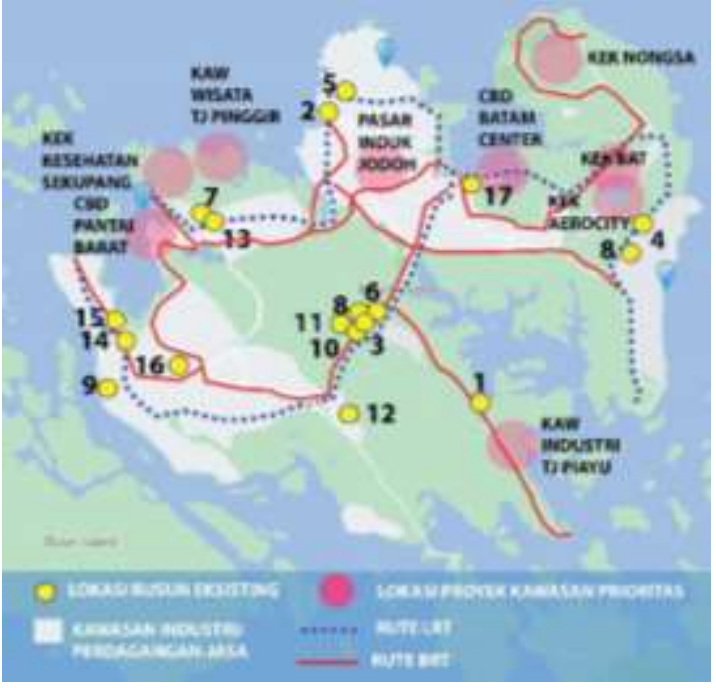

Gambar 6. Aksebilitas Rumah Susun ke Layanan Transportasi Publik

(Sumber: Hasil Analisis)

Berdasarkan hasil pemetaan, dapat dilihat beberapa temuan sebagai berikut:

- Sebagian besar Rumah Susun eksisting dilalui oleh rencana trayek LRT/BRT Batam.

- Terdapat beberapa lokasi Rusun yang dilalui oleh jalur baik LRT maupun BRT sehingga memiliki opsi transportasi yang sangat strategis karena adanya pilihan trayek.

- Rumah Susun Tembesi memiliki lokasi yang belum dilalui jalur LRT/BRT sehingga perlu dipertimbangkan adanya suatu feeder yang memadai untuk mendukung potensi aksebilitas yang lebih baik.

- Hampir seluruh lokasi Rumah Susun yang ada, jika dihubungkan dengan layanan transportasi publik, akan memiliki aksebilitas yang lebih baik ke lokasi pengembangan kawasan prioritas.

- Kawasan dengan tingkat populasi penghuni terbesar berada di sekitar Kawasan Muka Kuning, dimana terdapat 5 lokasi rusun dengan sekitar penghuni bisa mencapai sekitar 8.000 jiwa. Hal ini perlu menjad perhatian dalam penyiapan kapasitas angkut 
dari LRT/BRT yang melalui lokasi tersebut.

Tabel 5. Rumah Susun dan Aksebilitas terhadap Transportasi Publik

\begin{tabular}{|c|c|c|}
\hline No & Rumah Susun & $\begin{array}{c}\text { Potensi } \\
\text { Layanan } \\
\text { Transportasi }\end{array}$ \\
\hline 1 & Perumnas Tj Piayu & BRT \\
\hline 2 & $\begin{array}{l}\text { Jamsostek Batu } \\
\text { Ampar }\end{array}$ & BRT/LRT \\
\hline 3 & $\begin{array}{l}\text { Jamsostek Muka } \\
\text { Kuning }\end{array}$ & BRT/LRT \\
\hline 4 & Jamsostek Kabil & BRT \\
\hline 5 & BP Batam Batu Ampar & LRT \\
\hline 6 & $\begin{array}{l}\text { BP Batam Muka } \\
\text { Kuning }\end{array}$ & BRT/LRT \\
\hline 7 & BP Batam Sekupang & BRT \\
\hline 8 & BP Batam Kabil & BRT \\
\hline 9 & BP Batam Tj Uncang & LRT \\
\hline 10 & Pemko Muka Kuning & BRT/LRT \\
\hline 11 & $\begin{array}{l}\text { Pemko Muka Kuning } \\
2\end{array}$ & BRT/LRT \\
\hline 12 & Pemko Tembesi & BRT \\
\hline 13 & Pemko Sekupang & BRT \\
\hline 14 & Pemko Tj Uncang 1 & BRT/LRT \\
\hline 15 & Pemko Tj Uncang 2 & BRT/LRT \\
\hline 16 & Pemko Tj Uncang 3 & BRT/LRT \\
\hline 17 & REI & BRT/LRT \\
\hline
\end{tabular}

Sumber: Hasil Analisis

\section{KESIMPULAN}

Berdasarkan dari hasil analisis untuk melihat hubungan antara lokasi Rumah Susun dan potensi aksebilitas transportasi publik yang ada, maka dapat diambil kesimpulan sebagai berikut:

- Rumah Susun di Batam saat ini umumnya berkembang di sekitar aktivitas kegiatan industri, perdagangan dan pelabuhan.

- Rumah Susun yang ada saat ini memiliki aksebilitas cukup strategis ke beberapa kawasan strategis di Batam seperti pusat kota Batam Center-NongsaSekupang, sentra industri di Panbil, Sagulung maupun area perdagangan dan jasa di Nagoya-Lubuk Baja melalui ketersediaan jaringan jalan di sekitar kawasan Rumah Susun.

- Rencana pengembangan kawasan prioritas di Batam akan berdampak pada peningkatan populasi yang sejalan dengan pengingkatan kebutuhan akan hunian untuk pekerja pada kawasankawasan strategis Batam.

- Posisi Rumah Susun yang ada saat ini berjarak rata-rata sekitar 2-6 kilometer sehingga pengembangan perumahan ideal yang memungkinkan mobilitas berjalan kaki ke tempat kerja belum dapat diterapkan dengan lokasi Rumah Susun yang ada saat ini, karena jarak tempuh yang masih relatif jauh ke lokasi potensi tempat bekerja.

- Sehubungan dengan pola transportasi di Batam yang masih didominasi kendaraan pribadi, maka aksebilitas menuju Rumah Susun juga masih belum terhubung dengan moda transportasi yang terpadu.

- Rencana pengembangan transportasi massal berupa LRT dan BRT memiliki jalur yang melintasi beberapa lokasi Rumah Susun yang ada saat ini, berpotensi untuk mendukung kebutuhan hunian pada kawasan prioritas yang akan dikembangkan.

- Keberadaan Rumah Susun yang terhubung dengan jalur transportasi massal dapat memberikan suatu daya tarik sendiri sehingga masyarakat akan tertarik untuk tinggal di Rumah Susun karena berpotensi menghemat biaya transportasi jika menggunakan kendaraan pribadi.

- Pengalihan dominasi transportasi dari kendaraan pribadi menjadi dominan transportasi publik akan mendukung terciptanya Kota Batam yang berkelanjutan di masa datang.

Dalam kaitannya untuk strategi pengembangan kawasan prioritas di masa datang dan ketersedian dukungan 
perumahan, maka perlu dilakukan beberapa pendekatan antara lain:

- Melakukan kajian mengenai daya tampung dari lokasi Rumah Susun yang ada, apakah masih memungkinkan pengembangan twin blok baru untuk mendukung pemenuhan akan hunian dari kawasan prioritas yang baru dikembangkan.

- Membuat suatu zonasi pengembangan/pembangunan

Rumah Susun yang berbasis pada aksebilitas menuju tempat aktivitas. Hal ini bisa antara lain berupa upaya untuk pengembangan lokasi baru Rumah Susun yang berada dekat dengan kawasan pengembangan prioritas atau penyiapan lokasi Rumah Susun Baru di dekat akses transportasi publik.

- Pada kawasan yang dikembangkan dengan konsep TOD pada simpulsimpul stasiun LRT, dapat diusulkan adanya porsi untuk pengembangan hunian vertikal untuk MBR, yang untuk menyikapi terhadap nilai ekonomis lahan, dapat dilakukan dengan skema subsisdi silang dengan hunian vertikal non subsidi.

\section{DAFTAR PUSTAKA}

BP Batam. 2017. Studi Evaluasi Transit Oriented Development (TOD) Pengembangan LRT/Moda Transportasi Berbasis Rel di Batam. Batam: BP Batam

Damuri, Yose Rizal, et al. 2015. Kawasan Ekonomi Khusus dan Strategis di Indonesia: Tinjauan atas Peluang dan Permasalahan. Yogyakarta: Kanisius.

Dinas Tata Kota Kota Batam. 2009. Profil Pengembangan Pembangunan Rusunawa Dan Rusunami di Kota Batam. Batam: Dinas Tata Kota Batam
Kumar, Sree \& Sharon Shiddqiq. 2020. Batam. Whose Hinterland? Singapore: Select Publishing.

Kemenko Bidang Perekonomian Republik Indonesia Deputi Pengembangan Wilayah Pengembangan Wilayah dan Infrastruktur.2020. Laporan Kajian Rencana Induk Pengembangan KPBPB Batam, Bintan, Karimun Tahun 2020-2045. Jakarta: Tim Penyusun Rencana Induk Pengembangan KPBPB Batam, Bintan, Karimun

Kementerian Pekerjaan Umum dan Perumahan Rakyat.2020. Hunian Berbasis Transit (TOD): Tantangan dan Potensinya. Jakarta: Kementerian Pekerjaan Umum dan Perumahan Rakyat

Murbiantoro, Tito, M. et al. Model Pengembangan Hunia Vertikal Menuju Pembangunan Perumahan Berkelanjutan. Jurnal Permukiman Vol 4. No. 2 September 2009. (hal.72-87)

Murtiono, Hendro, et al. 2020. Peran Hunian Vertikal Sebagai Solusi Terhadap Kawasan Kumuh Di Kota Batam Kepulauan Riau. Arcade Jurnal Arsitektur Vol 4 No 1 Maret 2020 (hal. 47-51),

Republik Indonesia. 2011. Undang-Undang Nomor 1 Tahun 2011 tentang Perumahan dan Permukiman. Lembaran Negara Republik Indonesia Tahun 2011 Nomor 7.

Sabaruddin, Arif. 2018. Hakekat Hunain Vertikal di Perkotaan. Prosiding Seminar Kota Layak Huni / Livable Space. Jakarta: Universitas Trisakti 